РОЗРОБКА ТА ВПРОВАДЖЕННЯ СТРУКТУРНОЇ МОДЕЛІ ФОРМУВАННЯ ПЕДАГОГІЧНОЇ КУЛЬТУРИ НА ЗАСАДАХ АКМЕОЛОГІЧНОГО ПІДХОДУ У ПРОФЕСІЙНУ ПІДГОТОВКУ МАЙБУТНІХ СОЦІАЛЬНИХ ПРАЦІВНИКІВ

\author{
DEVELOPMENT AND IMPLEMENTATION OF A STRUCTURAL MODEL \\ FOR THE FORMATION OF A PEDAGOGICAL CULTURE BASED \\ ON THE PRINCIPLES OF ACMEOLOGICAL APPROACH \\ IN THE TRAINING OF FUTURE SOCIAL WORKERS
}

УДК 378:37.091.12:36-051 DOI https://doi.org/10.32843/2663-60852019-14-1-13

\section{Келемен А.B.,}

директор

Карпатського інституту підприємництва Відкритого міжнародного університету розвитку людини «Україна» у статті обгрунтовано потребу використання педагогічного моделювання, яке позитивно впливатиме на формування педагогічної культури майбутніх соціальних працівників. Запропоновано авторське бачення структурної моделі, у якій чільне місце відведено акмеологічному підходу. Розглянуто підходи до наукової дефрініції «структурна модель». Модель розглядаємо як самостійний об'єкт, що відповідає досліджуваному процесу, здатний заміщати його та виступати опосередкованою ланкою в пізнанні. Модель надає практичну інформацію, яка дозволяє ефективно формувати педагогічну культуру в майбутніх соціальних працівників на засадах акмеологічного підходу. Структурна модель $є$ «дзеркальним відображенням» професійної підготовки майбутніх соціальних працівників у закладах вищої освіти.

Встановлено, що в основі структурноі моделі має бути професіограма, що передбачає «еталонну модель» соціального працівника. Проаналізовано психолого-педагогічні ідеї, що покладені в основу авторської структурної моделі. У структурній моделі представлено три блоки (цільово-концептуальний, процесуально-організаційний оцінювально-результативний), які охоплюють мету, завдання, навчальні дисципліни, акмеологічний підхід, принципи, організаційнопедагогічні умови, методи, срорми, прийоми побудови освітнього прочесу, а також компоненти, критерії ссрормованості педагогічної культури, рівні та результат. Головна увага зосереджена на характеристиці основних принципів (гуманізм, співробітничтво, культуровідповідність, суб'єктність), які покладено в основу структурної моделі. З'ясовано, що в методологічному контексті впровадження структурної моделі фрормування педагогічної культури на засадах акмеологічного підходу у профресійну підготовку майбутніх соціальних працівників дасть позитивні результати. Так, очікуємо покращення стану сорормованості компонентів педагогічної культури (мотиваційно-ціннісний, когнітивно-аксіологічний, конативно-діяльнісний, рефрлексивно-особистісний).
Ключові слова: структурна модель, педагогічна культура, акмеологічний підхід, принципи, майбутні соціальні працівники.

The article substantiates the need for pedagogical modeling, which will have a positive impact on the formation of the pedagogical culture of future social workers. The author's vision of a structural model is proposed, in which the emphasis is placed on the acmeological approach. Approaches to the scientific definition of "structural model" are considered. The model is considered as an independent object, which is in accordance with the investigated process, capable of replacing it and acting as an indirect link in the cognition. The model provides practical information that allows to effectively implement the formation of pedagogical culture in future social workers on the basis of the acmeological approach. The structural model serves as a "mirror image" of the professional training of future social workers in HEl.

It has been established that the structural model should be based on a professional diagram, which involves a "reference model" of a social worker. The psychological and pedagogical ideas, which are the basis of author's structural model, are analyzed. In the structural model, there are three blocks (target-conceptual, procedural-organizational and evaluation-productive), which include the purpose, tasks, educational disciplines, acmeological approach, principles, organizational and pedagogical conditions, methods, forms, methods of constructing the educational process, as well as components, criteria for the formation of a pedagogical culture, levels and result. The main focus is on the characterization of the basic principles (humanism, cooperation, cultural conformity, subjectivity), which are the basis of the structural model.

It is revealed that in the methodological context of the introduction of a structural model of formation of a pedagogical culture on the basis of the acmeological approach in the professional training of future social workers will give positive results. So, we expect an increase in the state of the formation of components of pedagogical culture (motivationalvaluable, cognitive-axiological, connative-active, reflexive-personal).

Key words: structural model, pedagogical culture, acmeological approach, principles, future social workers.
Постановка проблеми в загальному вигляді. Період навчання в закладах вищої освіти (далі-3ВО) $€$ одним із найвідповідальніших у процесі становлення особистості майбутнього фрахівця, який працюватиме в соціальній сорері. Це час, коли фрормуються основні ціннісні настанови й життєва позиція, закладається ставлення до навколишньої дійсності та до своєї майбутньої профресії. Тому необхідно, щоб у цей період освіта за своїм змістом стала фун- даментом для подальшого вдосконалення цінностей і норм культури, була акцентована на орормування високого рівня педагогічної культури. Саме майбутній соціальний працівник має володіти належним рівнем педагогічної культури, що допоможе йому якісно виконувати свої профресійні обов'язки. Беручи до уваги те, що нині суттєво зросли вимоги до майбутніх фрахівців, які надаватимуть соціальні послуги, необхідно внести суттєві зміни в їхню професійну 
підготовку. У нашому баченні ці зміни мають стосуватися запровадження педагогічних інновацій, які пов'язані $з$ використанням у професійній підготовці педагогічного моделювання.

Аналіз останніх досліджень і публікацій. Теоретичні та практичні питання професійної підготовки майбутніх соціальних працівників вивчалися І. Звєрєвою, І. Козубовською, Л. Міщик та ін. Психолого-педагогічні шляхи вдосконалення профресіоналізму майбутніх соціальних працівників досліджували Н. Волкова, В. Корнещук, С. Тополянський, Ю. Швалб та ін. 3'ясовано, що в публікаціях О. Онаць, С. Чорної та П. Щербаня висвітлено зміст і структуру педагогічної культури. Ідеї педагогічного моделювання розробляються закордонними педагогами і психологами гуманістичного спрямування (Р. Берні, Н. Боуерс, Б. Кларк, Р. Соур, Д. Хопкінс, П. Холлі й ін.). З'ясовано, що потенціал педагогічного моделювання під час професійної підготовки майбутніх соціальних працівників вивчали І. Мельничук, С. Калаур, В. Поліщук, Г. Слозанська. Зокрема, погоджуємося з думкою Г. Слозанської [6] стосовно того, що нині підвищеної уваги потребують розроблення та впровадження дієвих моделей соціальної роботи і механізмів надання соціальних послуг у систему підготовки майбутніх соціальних працівників у ЗВО.

Виділення не вирішених раніше частин загальної проблеми. Підтримуємо позицію науковців [3] у тому, що лише той фрахівець, який озброєний прогресивною системою, сорормований як творча, соціально активна особистість, яка вміє нестандартно та творчо мислити, професійно діяти, створювати нові суспільні цінності. У нашому баченні панівну роль у фрормуванні особистості майбутнього соціального працівника відіграють системоутворюючі якості: мотиваційно-ціннісне ставлення до майбутньої профресії, профресійне мислення, готовність до просресійної діяльності та педагогічна культура. Зазначимо, що в контексті вдосконалення процесу формування педагогічної культури фрахівців непедагогічних спеціальностей назріла потреба розроблення моделі, яка була б дієвою під час фрормування педагогічної культури майбутніх соціальних працівників. Однак ці питання не були предметом ґрунтовних наукових досліджень. Саме тому ми проводимо наукові розвідки стосовно вивчення потенціалу педагогічного моделювання й розроблення та впровадження структурної моделі у професійну підготовку майбутніх соціальних працівників.

Мета статті - дослідити потенціал педагогічного моделювання і проаналізувати зміст структурної моделі та шляхи її впровадження для вдосконалення профресійної підготовки майбутніх соціальних працівників у контексті фрормування в них педагогічної культури на засадах акмеологічного підходу.

Виклад основного матеріалу. Аналіз теоретикометодологічних підходів до професійної підготовки майбутніх фрахівців соціальної сфери переконує, що всі вони так чи інакше пов'язані з фрормуванням профресіоналізму, сприяють удосконаленню його майстерності. У контексті цього потребує уваги процес фрормування педагогічної культури на засадах акмеологічного підходу шляхом використання педагогічного моделювання та впровадження у професійну підготовку майбутніх соціальних працівників структурної моделі.

Як доводять науковці, для дослідження об'єктів пізнання, побудови і вивчення моделей предметів і явищ, що реально існують, а також конструювання об'єктів (для визначення й уточнення їхніх характеристик, раціоналізації, способів побудови) еорективне використання процесу моделювання. Уважаємо, що педагогічне моделювання $є$ шляхом пізнання педагогічних явища лише тоді, коли воно здійснюється на основі вже сорормованої теорії досліджуваного процесу, що вказує гранично допустимі під час побудови моделі спрощення. Тобто на ідеї використання педагогічного моделювання базується будь-який метод наукового дослідження як теоретичний, так і експериментальний.

Сьогодні у професіійній педагогіці розробляється модель ідеального фрахівця і його профресійної підготовки у ЗВО. Ця модель має включати такі істотні ознаки та якості, як здатність одночасно навчати і виховувати, орормування ґрунтовної теоретичної освіти, високий ступінь усвідомлення цінностей професійної діяльності, відповідальність за результати своєї роботи. У педагогічному розумінні наукову дефрініцію «модель» ми розглядаємо як конкретну систему елементів, яка відтворює певні сторони, зв'язки, орункції предмета дослідження (у нашому випадку це фрормування педагогічної культури в майбутніх соціальних працівників - А. К.). У нашому дослідженні визначаємо, що модель - це самостійний об'єкт, що відповідає досліджуваному процесу, здатний заміщати останній, виступати опосередкованою ланкою в пізнанні та надає під час дослідження конкретну практичну інформацію, яка дозволяє нам ефективно здійснювати корекцію всієї профресійної підготовки майбутніх соціальних працівників у контексті фрормування в них педагогічної культури на засадах акмеологічного підходу.

У педагогічній науці виділяють безліч різноманітних моделей. В основі класифікації лежать такі ознаки, як: вид (змістовні та фрормальні моделі); спосіб реалізації моделі (образні, знакові (графрічні) і змішані моделі); облік (статистичні, динамічні та детерміновані); характеристика об'єкта моделювання (модель зовнішнього вигляду, модель структури і модель фрункціонування або процесу). Створена нами модель формування педагогічної культури в майбутніх соціальних працівників є структурною, в основі якої лежать сутнісні зв'язки й відносини між iї найважливішими компонентами. Підкреслимо, що структурна модель, у нашому розумінні, є певним «дзеркальним відображенням» професійної 
підготовки майбутніх соціальних працівників у 3ВО. Саме структурна модель дозволяє нам провести абстрагування її змісту та подальше зіставлення й порівняння $з$ об'єктом-оригіналом. Уважаємо, що розроблення та впровадження структурної моделі дозволить нам «відсікти» усе другорядне та випадкове, а залишити лише вагомі чинники, які суттєво впливають на процес удосконалення педагогічної культури майбутніх соціальних працівників під час їхньої фрахової підготовки. Наступна причина, через яку ми скористалися методом педагогічного моделювання, - це передбачувальна фрункція моделі, яка дозволяє отримувати нову інфрормацію про процес фрормування педагогічної культури.

Зупинимося на загальній характеристиці методологічних аспектів побудови структурної моделі. Так, у монограсрії «Теоретико-методологічні засади фрормування змісту педагогічної освіти» [4] представлено загальний варіант побудови структурованої моделі. Зокрема, ураховано позицію науковців про необхідність складання кваліфікаційної характеристики фрахівця-майстра як свідомого суб'єкта професійної діяльності й активного діяча суспільного розвитку, а також думка про те, що цей фракт стримує складання ідеальної моделі майбутнього фрахівця, що відповідає вимогам сучасного суспільства [4, с. 29-34].

У методологічній площині враховані поради В. Сластеніна [5] стосовно того, що основними структурними компонентами моделі має бути мета, принципи, професійна компетентність (знання, уміння, навички), якості особистості. Отже, у методологічному контексті ми прагнули, щоби структурна модель включала в себе опис соціальної та професійної спрямованості особистості в контексті головних засад акмеологічного підходу та творчої природи професійної діяльності, загальні аспекти профресійної підготовки студентів у ЗВО (мета, принципи, методи, фрорми, етапи), структурну характеристику педагогічної культури (компоненти, критерії, рівні, результат).

Під час педагогічного моделювання ми спиралися на такі рекомендації:

- в основі має бути професіограма, що передбачає «еталонну модель» соціального працівника;

- необхідність подолати розрив між соціальним працівником-людиною, громадянином і його професійними знаннями, уміннями і навичками (ідеться про те, щоб інтегрувати особистісну позицію майбутнього соціального працівника і його профресійні знання і вміння);

- скерування на вдосконалення індивідуальноособистісного рівня професіоналізму майбутнього фрахівця через удосконалення педагогічної культури.

Тобто у практичному контексті в основу структурної моделі покладено профресіограму. У баченні Л. Спіріна [7] саме професіограма розглядається як ідеальна абстрактна модель особистості фрахівця, що узагальнює найважливіші якості, необхідні для здійснення професійної діяльності в сучасних умовах. Профресіограма має включати спрямованість особистості, його професійні потреби, мотиви, основні види діяльності, властивості особистості, що виражають громадянську і професійну спрямованість; інтелектуальні, моральні, вольові, емоційні риси характеру; професійні вміння та навички. Таку позицію обстоює С. Калаур [2], яка доводить, що профресіограма являє собою сукупність вимог, що пред'являються до профресіоналізму майбутнього соціального працівника. Зокрема, обумовлюючи орієнтири професіограми, під час побудови структурної моделі, ми спираємося на системний аналіз концептуальних підходів і цільових програм професійної підготовки майбутніх соціальних працівників: систему панівних мотивів і потреб; професійні знання, уміння і здібності; найважливіші особистісно-просресійні якості та властивості особистості; готовність до профресійної діяльності. На основі запропонованого зазначимо, що авторська модель має охоплювати конкретні вимоги до особистості соціальної працівника; психолого-педагогічну, спеціальну і методичну підготовку у ЗВО.

В основу нашої авторської структурної моделі закладено дві головні ідеї:

- робота на випередження, яка передбачає включення соціального працівника в розв'язання більш складних завдань, які необхідні для якісного виконання професійних завдань;

- спрямування моделі на суттєве математично достовірне підвищення рівня педагогічної культури соціального працівника.

Структурна модель фрормування педагогічної культури майбутніх соціальних працівників являє собою конкретну сукупність найважливіших складників - структурних блоків. Виокремлено три блоки:

1) цільово-концептуальний (мета, завдання, навчальні дисципліни, акмеологічний підхід, принципи);

2) процесуально-організаційний (організаційнопедагогічні умови, методи, фрорми, прийоми);

3) оцінювально-результативний (компоненти і критерії ссрормованості педагогічної культури, рівні, результат).

Наголосимо на тому, що акмеологічний підхід визнано профілюючим для фрормування педагогічної культури майбутніх соціальних працівників. Цей фракт зумовлений тим, що акмеологічний підхід максимально забезпечує оволодіння способами пізнання навколишньої дійсності, професії та самого себе для самореалізації у професійній діяльності. Цей підхід покладено в основу розроблення навчальних дисциплін «Основи самопізнання і саморозвитку особистості», «Тренінг самопізнання», «Основи акмеології», «Менеджмент у соціальній роботі», «Соціальне проєктування», «Управління проєктами», які максимально сприяють фрормуванню педагогічної культури майбут- 
ніх соціальних працівників, що здобувають освіту на базі Карпатського інституту підприємництва Відкритого міжнародного університету розвитку людини «Україна».

У нашому баченні формування педагогічної культури майбутніх соціальних працівників перебуває під егідою принципів гуманізму, співробітництва, культуровідповідності, суб'єктності. Саме ці принципи становлять інваріантну частину цільово-концептуального блока нашої моделі. Розглянемо їхні практичні механізми ґрунтовніше.

Отже, практичне впровадження принципу гуманізму передбачає ставлення до студентів як до головної цінності, повагу до їхніх думок, створення умов, за яких особистість відчуває себе захищеною, потрібною, значущою. Принцип співробітництва передбачає об'єднання цілей викладачів і студентів, організацію спільної діяльності зі «сходження до високого результату педагогічної культури», взаєморозуміння і взаємодопомогу під час організації освітнього процесу. Принцип культуровідповідності орієнтує всю професійну підготовку на ставлення до студента як до суб'єкта, здатного до самоактуалізації й саморозвитку; до викладача як посереднику між студентом і культурою, що здатний увести студента у світ культури; до фоормування педагогічної культури як культурного процесу; до ЗВО як до цілісного культурно-освітнього простору, де відтворюються культурні норми, здійснюються «творіння педагогічної культури» і фрормування майбутнього соціального працівника людини культури. Принцип суб'єктності передбачає сприяння викладача у фрормуванні у студентів здатності бути суб'єктом власної діяльності і свого життя.

Отже, розроблена нами структурна модель фрормування педагогічної культури, яка створена на основі акмеологічного підходу, базується на принципах культуровідповідності, суб'єктності, гуманізму, співробітництва, інтегрує конкретну організаційну структуру (мета, етапи, навчальні дисципліни, організаційно-педагогічні умови, методи, фрорми, компоненти і критерії сорормованості педагогічної культури, рівні), сприяє цілісності досліджуваного процесу, забезпечує позитивну динаміку у процесі формування педагогічної культури майбутнім соціальним працівникам ще під час навчання у ЗВО (результат). Ми очікуємо від упровадження розробленої структурної моделі суттєвого підвищення рівня сорормованості всіх компонентів педагогічної культури (мотиваційно-ціннісний, когнітивно-аксіологічний, конативно-діяльнісний, рефрлексивно-особистісний).

У підсумку зазначимо, що ми підтримуємо позицію В. Андреєва в тому, що у XXI ст. майбутні фрахівці повинні будуть вирішувати ще більш складні професійно-педагогічні проблеми, які потребуватимуть інтеграції знань, практичних умінь. Тому ще під час навчання у ЗВО студент має навчитися «безперервно оволодівати прогресивними технологіями навчання і виховання, новими досягненнями вітчизняного і зарубіжного досвіду та мати високу педагогічну культуру» [1, с. 90]. У нашому баченні саме педагогічне моделювання, розроблення та впровадження структурної моделі націлені на практичну допомогу майбутнім соціальним працівникам щодо формування в них високого рівня педагогічної культури ще під час навчання.

Висновки. 3 метою фрормування належного рівня педагогічної культури в майбутніх соціальних працівників доцільно використовувати педагогічне моделювання. Із практичного погляду пропонуємо впровадити структурну модель фрормування педагогічної культури на засадах акмеологічного підходу. У структурній моделі представлено три блоки (цільово-концептуальний, процесуально-організаційний, оцінювально-результативний), які охоплюють мету, завдання, навчальні дисципліни, акмеологічний підхід, принципи, організаційно-педагогічні умови, методи, фооми, прийоми побудови освітнього процесу, а також компоненти, критерії сфрормованості педагогічної культури, рівні та результат.

У подальших напрацюваннях плануємо висвітлити організаційно-педагогічні умови, які покладено в основу дієвості структурної моделі, та представити практичні механізми їх упровадження у професійну підготовку майбутніх соціальних працівників для орормування в них високого рівня педагогічної культури.

\section{БІБЛІОГРАФІЧНИЙ СПИСОК:}

1. Андреев В. Модели творчески саморазвивающейся личности XXI в. Москва : Просвещение, 2001. $255 \mathrm{c}$.

2. Калаур С. Контент-аналіз профессіограми фрахівця соціальної сорери, компетентного у розв'язанні профресійних конфліктів. Social Work and Education. 2018. Vol. 5. № 1. P. 18-28.

3. Караханова Г. Теоретико-методологические основы исследования нравственной культуры учителя. Москва, 2005. 143 с.

4. Мищенко А., Мищенко Л., Шиянов Е. Теоретико-методологические основы формирования содержания педагогического образования. Москва, 1991. 291 c.

5. Сластенин В. Профрессионально-педагогическая культура в системе университетского педагогического образования. Профрессиональнопедагогическая культура: сущность, структура, формирование : материалы Международной научной конференции. Москва : МОСУ, 1996. С. 7-14.

6. Слозанська Г. Компетентнісна модель фрахівця із соціальної роботи в громаді. Освіта Сумщини : інформаційний науково-методичний журнал. Суми : КЗ СОІППО, 2018. № 3 (39). С. 16-19.

7. Спирин Л. Педагогика решения учебновоспитательных задач : учебное пособие. Кострома : КГПУ им. Н.А. Некрасова, 1994. 107 с. 